\title{
Uddannelse som social kunstform?
}

\section{Kunstneriske og padagogiske dilemmaer iforskning med kunstfaglig uddannelse}

\author{
Helene Illeris $\star$ \\ Universitetet $i$ Agder
}

\begin{abstract}
Dansk abstract
Målet med denne artikel er at undersøge nogle af de kunstneriske og pædagogiske dilemmaer, der kan opstå, når man anvender praksisstyret aktionsforskning i udviklingen af egen undervisning i og gennem de kunstneriske fag ved et universitet. Ved at fokusere på vanskelige situationer ønsker artiklen at diskutere, hvad der sker, når lærere og studerende sammen udforsker egne roller i de utydeligt afgrænsede mellemrum og spændinger mellem praksisformerne undervisning, forskning og kunst. I første del af artiklen præsenteres didaktiske, kunstneriske og metodiske aspekter af forskningsprojektet Art as Education/Education as Art, hvor min kollega og jeg i efteråret 2016 sammen gennemførte en undersøgelse knyttet til spørgsmålet: Hvad sker der, hvis vi, sammen med studerende og kolleger, betragter vores egen uddannelsespraksis som en kunstform? I artiklens anden del stilles der skarpt på dilemmaer og konflikter mellem undervisernes intentioner og de studerendes forventninger og mellem relationelle og antagonistiske tilgange til social kunst. Endelig diskuterer artiklen studerendes og læreres muligheder for at bebo deres egen undervisnings- og uddannelsespraksis over tid med udgangspunkt i begrebet arbejde.
\end{abstract}

Key words: Kunst som social praksis; masteruddannelse; kunstnerisk forskning; praksisstyret forskning; aktionsforskning

\section{English abstract}

The goal of this article is to explore some of the artistic and pedagogical dilemmas that appeared in an inquiry conducted in the autumn of 2016 at the Master's Programme in the Arts at the University of Agder in Norway as part of the research project Art as Education/Education as Art. The inquiry was conducted through practice-led action research, an open-ended and collaborative research methodology developed by the researcher-teachers in order to examine their own educational practices together with students and colleagues. Inspired by contemporary art practices the inquiry aimed to explore the question: What happens if we consider the educational practice in which we take part as a social arts practice? The first part of the article presents the structure of the Master's programme and discusses educational, artistic, and methodological aspects of the inquiry with a special focus on ethical dilemmas. The second part of the article uses a field-based

^Korrespondanse: Helene Illeris, Fakultet for Kunstfag, Universitetet i Agder, Postboks 422, 4604 Kristiansand. Epost: helene.illeris@uia.no

(C) 2018 H. Illeris. This is an Open Access article distributed under the terms of the Creative Commons Attribution 4.0 International License (http://creativecommons.org/licenses/by/4.0/), allowing third parties to copy and redistribute the material in any medium or format and to remix, transform, and build upon the material for any purpose, even commercially, provided the original work is properly cited and states its license.

Citation: H. Illeris. "Uddannelse som social kunstform? Kunstneriske og pæedagogiske dilemmaer i forskning med kunstfaglig uddannelse". Fournal for Research in Arts and Sports Education, Special Issue: "A forske med kunsten» Vol. 2, 2018, pp. $23-38$. 
example from an evaluation meeting to focus on some of the conflicts encountered, firstly between the intentions of the researcher-teachers' and the students' expectations, and secondly between relational and antagonistic approaches to social arts practices. In conclusion, the article discusses possibilities for inhabiting practices of teaching and education over time as a form of on going labour.

Key concepts: Art as social practice; Master's programme; artistic research; practice-led research; action research

Received: January, 2018; Accepted: March, 2018; Published: March, 2018.

\section{Indledning}

When artistic practice claims to be pedagogic, it immediately creates conflicting criteria in my mind: art is given to be seen by others, while education has no image. Viewers are not students, and students are not viewers, although their respective relationships to the artist and teacher have a certain dynamic overlap (Bishop, 2012, s. 241).

Citatet fra den britiske kunsthistoriker Claire Bishop peger på nogle af de dilemmaer, der kan opstå, når man forsøger at blande praksisformerne kunst og uddannelse. For hvad sker der, når de faste roller opløses, og kunst ikke bare er objekt for undervisningen, men undervisningssituationen i sig selv betragtes som en social kunstform? Bliver læreren til kunstner og de studerende til publikum, sådan som Bishop hævder? Eller er det muligt at operere kreativt og didaktisk i det 'dynamiske overlap' mellem de forskellige positioner og derigennem skabe noget helt tredje - en ny social samværsform?

Med udgangspunkt i forskningsprojektet Art as Education/Education as Art og mere konkret i en undersøgelse gennemført på Master $i$ kunstfag ved Universitetet i Agder handler denne artikel om nogle af de kunstneriske og pædagogiske dilemmaer, der kan opstå, når man gennem praksisstyret aktionsforskning eksperimenterer med at betragte sin egen uddannelsespraksis som en social kunstform. Artiklen falder i to dele: Del I omhandler baggrunden for og udviklingen af undersøgelsen, herunder metodiske og etiske overvejelser. Del II diskuterer, med udgangspunkt $i$ en konkret situation fra et evalueringsmøde med et hold studerende, to af de specifikke dilemmaer, vi stødte på undervejs: dilemmaet mellem ligeværdighed og lærerstyring og dilemmaet mellem god social kunst som værende enten harmonisk eller konfliktsøgende. Afslutningsvis argumenterer artiklen for et tredje og mere dynamisk syn på kunstfaglig uddannelse som en fælles arbejdsform, der udvikles over tid.

\section{Del I: Udviklingen af projektet}

I efteråret 2016 gennemførte min kollega, førsteamanuensis i musik Tormod Wallem Anundsen, og jeg en undersøgelse på første år på masteruddannelsen i kunstfag ved Universitetet i Agder, som led i forskningsprojektet Art as Education/ 
Education as $A r t^{1}$. Undersøgelsen tog udgangspunkt i det åbne spørgsmål: Hvad sker der, hvis vi, sammen med studerende og kolleger, betragter vores egen uddannelsespraksis som en social kunstform?

Som forberedelse til projektet afholdt Tormod og jeg en række mini-kollokvier, hvor vi diskuterede aktuelle tekster om uddannelse og om kunstens rolle, både som indhold og som pædagogisk metode. Vi var optaget af samtidig kritisk tænkning relateret til det kunstpædagogiske område, herunder særligt tekster af kunstkritikerne Nicholas Bourriaud (2005) og Claire Bishop (2004, 2012), kulturteoretikeren Irit Rogoff (2006, 2010, 2016), filosoffen Jacques Rancière (1999, 2009, 2010) og pædagogerne Paulo Freire (1970) og Gert Biesta (2011). Med dette udgangspunkt besluttede vi at undersøge, hvordan vi i vores daglige virke kan skabe alternative praksisformer, der inddrager de tre indbyrdes overlappende områder: uddannelse, kunstfag og forskning.

På uddannelsesområdet tog projektet afsæt i Rogoffs og Biestas kritik af universitetssystemets stadigt mere virkelighedsfjerne måde at tilrettelægge studier på, hvor vi som undervisere oplever, at vi skal leve op til standardiserede normer og levere på forhånd beskrevne outputs. Som Rogoff så rigtigt påpegede i en forelæsning på Universitetet i Agder (Tribbensee, 2015) er konsekvensen for os, at vi oplever at arbejde $\mathrm{i}$ en slags dobbelt virkelighed, hvor vi på den ene side skal feede abstrakte og overordnede kvalitetssikrings - systemer, mens vi på den anden side skal håndtere en uddannelsesmæssig virkelighed præget af praktiske problemer, som for eksempel har at gøre med de studerendes vidt forskellige baggrunde og behov. Som et alternativ til denne tænkning ønskede vi at betragte den uddannelse, vi har ansvaret for, som et kunst- og forskningsbaseret fællesskab, hvor undervisere og studerende arbejder sammen i forskellige typer af skabende praksisser. Projektet Art as Education/Education as Art kan således ses som et forsøg fra vores side på at træde ud af universitetets orden for at skabe en egen stemme, eller for at bruge Rancieres (1999) terminologi, en dissens, gennem at praktisere uddannelse og forskning forankret $\mathrm{i}$ et andet menneskesyn end det opportunistiske syn, der karakteriserer de herskende uddannelsespolitiske idealer (Illeris, 2017, 2018; Pedersen, 2011).

Kunstfagligt tog vi udgangspunkt i den del af samtidskunsten, som går under samlebetegnelsen social praksis (Bishop, 2012, s. 1), det vil sige projekter, der har til fælles, at de er performative, processuelle og involverer publikum som deltagere i forskellige former for sociale fællesskaber. I social praksis skabes tætte forbindelser mellem kunsten og det levede liv samtidig med, at der også er tydelige tråde bagud, særlig til 1970, ernes performance, community art og site specific art (Illeris, 2017).Vi var indledningsvis optagede af Bourriauds (2005) begreb relationel cestetik. Her er tale om projekter, hvor hovedvægten ligger på et lavmælt, uforpligtende og harmonisk samvær mellem deltagerne - gerne inden for rammerne af en genkendelig hverdagsagtig praksis som at lave mad, spise, snakke, lege eller slappe af. En beslægtet type social praksis er med et samlebegreb blevet omtalt som kunstens predagogiske vending

${ }^{1}$ Tormod og jeg skriver artikler om projektet både sammen og hver for sig. Vi har været i løbende dialog om denne artikel, og Tormod har godkendt den endelige version. 
(Podesva, 2007; Rogoff, 2010). I disse projekter, som også er dem, Bishop refererer til i det indledende citat, arbejder kunstnere og kuratorer med kunst- og udstillingsprojekter, hvor de bevidst bruger formater hentet fra uddannelsesverdenen, for eksempel forelæsninger, gruppearbejde og workshops. Konkret vil det sige, at aktiviteter, som vi normalt ville kategorisere som 'undervisning', i stedet bliver fremstillet som 'kunst', en perspektivforskydning, som vi ønskede at bruge som et centralt kunstfagligt og pædagogisk greb i forskningsprojektet.

Forskningsmæssigt ønskede vi, inspireret af kunstnerisk og kunstbaseret forskning (Haseman, 2006; Leavy, 2018; Østern, 2017), at udvikle en åben undersøgelsestilgang, hvor vi forenede undervisning og empirigenerering i en række eksplorerende, kunstneriske og kollaborative processer. I modsætning til de stigende universitære krav til forskningsprojekter om et på forhånd fastlagt metodedesign ville vi lade projektets undersøgelser udvikle sig som en del af den fælles praksis, hvor vi på én gang underviste $i$, med og gennem vores egen forskning. Denne dobbelte praksis, som jeg vil komme nærmere ind på senere, valgte vi, med udgangspunkt i det engelske begreb practice-led research (Haseman, 2006) og det norske praksisledet forskning (Østern, 2017), at kalde for praksisstyret aktionsforskning.

\section{Master i kunstfag}

Master $i$ kunstfag er en to-årig uddannelse ${ }^{2}$, som optager studerende med baggrund inden for musik, teater og visuelle fag, hvilket vil sige, at de enten skal have bacheloruddannelse inden for et af disse kunstfag eller en lærer-/ pædagoguddannelse med mindst 60 ECTS-point i et af fagene ${ }^{3}$. Masteruddannelsen er således tvarcestetisk, fordi den går på tværs af kunstarterne, og den er tvcerfaglig, fordi der undervises både i kunst, forskning og pædagogik, og fordi disse tre områder behandles såvel teoretisk som gennem forskellige former for udøvende, kunstnerisk praksis.

Uddannelsens første år består af fire obligatoriske moduler, hvert på 15 ECTSpoint, hvor Tverrfaglig prosjekt og Vitenskapsteori og vitenskapelig metode løber parallelt i efterårssemesteret, og Kunstfagformidling og Kunstnerisk utviklingsarbeid løber parallelt i forårssemesteret. I begge semestre foregår undervisningen i en vekselvirkning mellem praksisorienterede workshops og forelæsninger kombineret med mindre seminarer. Hele uddannelsens andet år er helliget 60 ECTS-point-faget Masteropp$g a v e^{4}$, som afsluttes med en individuel eksamen, som enten kan tage udgangspunkt i en rent skriftlig opgave eller i en kombination af en skriftlig opgave og et kunstnerisk projekt ${ }^{5}$.

I efterårssemesteret 2016 havde vi på forhånd besluttet, at vi skulle forstærke integrationen af undervisningen på de to parallelle moduler Tverfaglig prosjekt og

\footnotetext{
${ }^{2}$ Uddannelsens norske betegnelse er Master $i$ kunstfag. En norsk master uddannelse svarer til en dansk kandidatuddannelse. Se mere om uddannelsen på www.uia.no/studier/kunstfag

${ }^{3}$ For en mere nøjagtig gennemgang af kravene se https://www.uia.no/studieplaner/programme/ MASTKUN

${ }^{4}$ Dansk: speciale

${ }^{5}$ Se også https://www.uia.no/studieplaner/topic/KF-500-1
} 
Vitenskapsteori og vitenskapelig metode. Dels ud fra et generelt mål om at udfordre den traditionelle opdeling mellem praktiske og teoretiske fag endnu mere end vi havde gjort hidtil, dels fordi vi, udover vores undervisningslokale på universitetet, havde fået råderet over nogle store, tomme værkstedshaller tilknyttet det nu nedlagte Agder Teater i centrum af Kristiansand, som vi mente var egnede til mere eksperimenterende arbejdsformer $\mathrm{i}$ begge de to moduler.

\section{Undersøgelsens design}

Metodisk ønskede vi at arbejde med en åben forskningstilgang uden en på forhånd stramt defineret problemformulering. Vores idé var som sagt, at vi ikke bare ville forske i vores egen uddannelsespraksis, men at vi også ville lade forskningen udvikle sig gennem denne praksis. Vi ønskede derfor at involvere de studerende som aktive medforskere, som, udover at generere materiale og ideer til et fælles dynamisk arkiv, selv deltog i projektets udformning gennem løbende dialoger. Det betød for eksempel, at når Tormod og jeg sammen underviste på en metodeworkshop i sensorisk etnografi, så var dette på én gang undervisning $i$ et pensum, en anledning til at generere forskningsmateriale og et udgangspunkt for ligeværdige diskussioner om metodiske fremgangsmåder i undersøgelsen. For at sikre deltagernes engagement planlagde vi endvidere månedlige erfaringsdelinger, hvor vi sammen med dem, der havde lyst, kunne udvikle en slags kollektiv forståelse af, hvad vi sammen og hver for sig oplevede i projektet, og om mulige veje videre. Inspireret af Irit Rogoffs (2016) slogan, Starting in the middle ønskede vi at holde fast i undersøgelsen som et kollaborativt kunst- og forskningsprojekt ved at udvikle vores design processuelt gennem praksis.

Som nævnt valgte vi at betegne undersøgelsens metodologi som praksisstyret aktionsforskning. Med praksisstyret mente vi, at vi, i modsætning til traditionel problemstyret kvalitiativ forskning, ville arbejde med forskning som induktiv og kreativ, hvor forskeren/kunstneren med udgangspunkt i konstruktionen af erfaringsbaserede startpunkter dykker ned i praksis for at se, hvad der dukker op (Haseman, 2006, s. 4). I stedet for data introducerede vi begrebet kreata (Staunæs og Bramming, 2011) for at understrege, at dokumentation altid medfører skabelse af nye, kreative, ikke-repræsenterende virkeligheder, som interagerer med os i selvstændige assemblager (Vannini, 2015). Endvidere betragtede vi det genererede forskningsmateriale som en del af den praksis, der foregik, hvad enten der var tale om en performanceworkshop under ledelse af en gæstelærer (som omtalt i Illeris, 2018), hvor vi filmede, lavede lyd, tog notater eller samlede andre produkter, eller en 'almindelig' forelæsning, holdt af en af os, hvor materialet dels kunne være egne noter og PowerPoints, dels kunne være deltagernes noter, tegninger, opgavebesvarelser eller lignende. Desuden blev spørgsmålet om hvem, der faktisk genererer data, ganske interessant, i og med at enhver praksis jo er med til at definere deltagernes rollefordeling. Den samme person kan altså, afhængigt af positioneringsmulighederne i den aktuelle praksis, optræde som studerende, lærer eller forsker, noget vi ønskede at eksperimentere med undervejs, afhængigt af de forskellige forskningssituationer vi involverede os i. 
Med aktionsforskning mente vi, at vi ønskede at placere vores projekt i en pædagogisk forskningssammenhæng som en type participatorisk forskning inspireret af Paulo Freire, hvor forskning forstås som en politisk orienteret, kollaborativ forandringsproces (Nielsen og Nielsen, 2015, s. 114). Ved at integrere det kunstnerisk-kreative element (at arbejde med uddannelse som en social kunstform) og det pædagogisk-forandrende element (at arbejde med uddannelse som en politisk handling) ønskede vi at undersøge hvilke andre måder at tænke pædagogik på, der kan opstå, når man udfordrer de traditionelle videnshierarkier. I modsætning til mere kendte former for pædagogisk udviklingsarbejde, hvor man arbejder ud fra på forhånd definerede mål og problemstillinger, ønskede vi at dreje aktionsforskningsmodellen i en mere åben retning, hvor forandringen først og fremmest drejede sig om i fællesskab at udforske muligheder for bedre integration af forskning, undervisning og kunstnerisk praksis. Det vil sige, at vi lagde vægt på at gribe de muligheder, der opstod undervejs, dels for at eksperimentere med roller og positioneringer, dels for at generere kreata $\mathrm{i}$ et naturligt samspil med det, der $\mathrm{i}$ øvrigt foregik.

\section{Etiske overvejelser}

En undersøgelse som denne, hvor de traditionelle magthierarkier, der gennemsyrer såvel undervisning som kunst, på en gang udfordres og aktiveres, giver anledning til en række etiske overvejelser både på forhånd og undervejs og både af praktisk og lidt mere abstrakt karakter. Jeg vil her i særlig grad komme ind på de overvejelser, der havde at gøre med de studerendes deltagelse i projektet, fordi dette, som vi også kommer til at se videre frem, var noget, som gav anledning til en række spændinger og dilemmaer undervejs i gennemførelsen.

På det praktiske niveau var det en udfordring at sikre de studerendes samtykke i forhold til om og hvordan, de ville indgå i undersøgelsen. Som allerede nævnt ønskede vi som udgangspunkt at involvere dem mest muligt i rollen som medforskere. På den anden side måtte vi også sikre deres rettigheder til ikke at medvirke og til at trække sig fra enhver deltagelse i undersøgelsen når som helst, samtidig med at de naturligvis skulle kunne fortsætte som studerende på holdet. Inden projektet gik i gang, havde vi på forhånd skitseret følgende mulige positioner for de studerende:

1. Fuldt deltagende, hvor de var vores medforskere, delte og genererede forskningsmateriale sammen med os og deltog i de månedlige erfaringsdelinger.

2. Delvis deltagende, hvor de, i det omfang de havde lyst, delte eget materiale produceret i undervisningen og accepterede at blive fotograferet og filmet undervejs (uden at der ville blive publiceret genkendelige billeder uden samtykke).

3. Ikke deltagende, hvor de ikke delte noget materiale, og hvor vi undgik, at deres tilstedeværelse blev dokumenteret (ved ikke at rette kamera mod dem og ved at slette/ bortklippe 
alt billedmateriale, hvor de var med), og at de ikke ville blive nævnt i forbindelse med projektet, heller ikke i anonymiseret form ${ }^{6}$.

Gennem at præsentere disse positioner mente vi at kunne sikre størst mulig gennemsigtighed i forhold til, hvordan de kunne vælge at deltage, samtidig med at vi var klar over, at ikke-deltagelse, trods alle forsøg på anonymisering, kunne blive vanskelig for os at garantere, dels fordi de studerende, qua deres rolle og pligter som studerende, reelt ikke kunne undgå at blive involverede i det fælles sociale rum, dels fordi det altid vil være relativt enkelt at spore, hvem der var studerende på uddannelsen i den aktuelle periode. Vores pragmatiske løsning på dette var at garantere, at vi ikke publicerede omtaler af undersøgelsen, uden at disse på forhånd er sendt til de studerende til gennemlæsning? ${ }^{7}$.

De største udfordringer opstod imidlertid undervejs omkring den gensidige udøvelse og opretholdelse af eksplicitte og implicitte magtforhold. Med eksplicitte magtforhold tænker jeg på den indiskutable dobbeltrolle, Tormod og jeg havde, hvor vi skiftede mellem at være forskere, som ønskede at involvere de studerende på lige fod, og at være lærere og vejledere, der medvirkede ved de studerendes eksaminer. Med implicitte magtforhold tænker jeg på, at det et langt stykke hen ad vejen var os, der sad med definitionsmagten over projektet. Dette var situationer, som ikke kunne ændres grundlæggende, men vi forsøgte at løse dilemmaet ved at være mest muligt gennemsigtige med, hvad vi gjorde både som lærere og som forskere og ved at stå til rådighed for løbende samtaler og selv tage initiativ til dem.

Både i uddannelse, forskning og kunst som social praksis er der en løbende risiko for, at deltagere, på trods af alle mulige etiske overvejelser fra lærerens/forskerens/ kunstnerens side føler sig udnyttet, objektificeret og endda misbrugt til formål, som hun/han ikke på forhånd var i stand til at gennemskue. Med vores åbne og kollaborative undersøgelsesdesign kunne vi på ingen måde forudsætte, at deltagerne var sikre på, hvad de sagde ja til, blandt andet af den simple grund at vi på mange måder heller ikke vidste det selv. For hvor langt kan eller bør man egentlig gå, når man arbejder med en kunstfaglig uddannelse, hvor deltagerne i forskellig grad forventes at lære ikke bare om, men også gennem deltagelse i kunstneriske projekter og i forskning? På en måde drejer kunst sig jo netop om forskellige typer af eksperimenterende selvoverskridelse - og gør læring i virkeligheden ikke også det? Og forskning? Hvordan kan vi reelt skabe noget nyt, hvis vi ikke udfordrer os selv og hinanden? Og hvor går grænsen for den enkelte?

\footnotetext{
${ }^{6}$ Deltagernes forskellige valg af positioner blev senere bekræftet i en skriftlig erklæring for at garantere informeret samtykke bedst muligt.

${ }^{7}$ Manuskriptet til denne artikel er således sendt til gennemlæsning og godkendelse hos de studerende både $\mathrm{i}$ en tidligere udgave og $\mathrm{i}$ den endelige version.
} 


\section{H. Illeris}

I den lille bog Education for socially engaged art (2011, s. xiv-xv) skriver kunstpædagogen Pablo Helguera, at selvom det ikke er hverken muligt eller ønskeligt at skabe et egentligt etisk regelsæt for sociale kunstprojekter, så er det så meget desto mere nødvendigt, at kunstnerne hele tiden er opmærksomme på de komplekse magtforhold, som sættes i gang, når man arbejder i menneskelige relationer. Den socialt engagerede kunstner har, på samme måde som læreren og forskeren, et ansvar for, at deltagerne eller samarbejdspartnerne ikke ufrivilligt gøres til et 'materiale' i et projekt, som de ikke føler ejerskab til. Omvendt mener Helguera, at kunstneren også må være nøjeregnende med ikke at gå på kompromis med projektets etiske integritet, og at her findes der ingen lette løsninger. Det, som virkelig tæller, er således den kontinuerlige opmærksomhed, empati og vilje til forhandling, forklaring, hensyntagen og ændring, også når dette er virkelig besværligt, og 'vi egentlig skulle noget andet' og 'vi jo har snakket om det før'. Således blev vores erfaring, som vi skal se, at når man giver sig tid, og når man erkender sine fejltrin undervejs uden af den grund at underkende selve projektet, så bliver etikkens vigtigste opgave at se, møde og forhandle konflikter, når de opstår, i stedet for ukritisk og fortravlet at henvise til på forhånd fastsatte regler og erklæringer.

\section{Del II: Dilemmaer}

I løbet af den første uge introducerede vi de nye studerende både for vores overordnede forskningsprojekt og for den undersøgelse, vi ønskede at gennemføre sammen med dem. Af 15 studerende valgte ni at prøve rollen som fuldt deltagende, fire valgte at være delvis deltagende, og to ønskede slet ikke at deltage. Vi valgte med vilje ikke at gå nærmere ind på den enkeltes personlige begrundelser for disse valg, men koncentrerede os i stedet om at finde praktiske løsninger, som løbende kunne beskytte og tilfredsstille alle bedst muligt. I forhold til genereringen af materiale til det fælles arkiv involverede vi fra begyndelsen dem, der ønskede det, i arbejdet med at tage notater, skrive fortællinger samt fotografere og filme undervejs, ligesom vi inviterede alle til at deltage i månedlige erfaringsdelinger. Ikke overraskende opstod der hurtigt en gruppe på 4-6 studerende, som virkelig deltog i disse aktiviteter. De øvrige gav undervejs i forløbet udtryk for, at de først og fremmest havde travlt med at finde sig selv i rollen som nye studerende, og at det blev for krævende for dem at skulle forholde sig aktivt til undersøgelsen og til vores mange idéer om uddannelse og forskning som kunst.

Jeg vil i denne del af artiklen prøve at forfølge nogle af de dilemmaer, vi oplevede undervejs i undersøgelsen. Som eksempel på kreata vil jeg bruge en genfortælling af mine oplevelser fra et evalueringsmøde, vi havde med de studerende i november 2016. Fortællingen tager udgangspunkt i Tormods og mine egne notater, men den er bearbejdet efterfølgende med henblik på denne artikel. Efter den vil jeg diskutere to af de dilemmaer, jeg mener, fortællingen indeholder. Det første omhandler spørgsmålet om lighed mellem positioner, og hvordan, hvornår og af hvem 
henholdsvis lighed og ulighed skabes og erfares. Her bruger jeg Rancières begreber dissens og subjektifikation som diskussionspartnere. Det andet dilemma omhandler forholdet mellem relationalitet og antagonisme. Her bruger jeg igen Rancière, men nu kombineret med de allerede nævnte kunstfaglige teorier af Bourriaud (2005) og Bishop (2012) og suppleret med Grant Kesters (2011) syn på kunst som arbejde.

\section{Evalueringsmødet, november 2016}

Vi sidder $i$ en gruppe $i$ et klasselokale med ansigterne vendt mod hinanden. Nogle sidder på stole, andre $i$ et par gamle sofaer. Atmosfæren er an spændt. Der skal være midtvejsevaluering, både af undervisningen og af de studerendes deltagelse $i$ forskningsprojektet. Vi lærere er nervøse, faktisk utilpasse. Vi ved jo, at de studerende er frustrerede, og at der vil være klager. Nu skal alt på bordet.

Evalueringsmødet åbner med, hvad Tormod og jeg oplever som en kaskade af indvendinger: teatret er koldt, der lugter muggent, akustikken er an elendig, der er larm fra tilstødende lokaler, og det ubehageligt at opholde sig der, ikke mindst for dem, der $i$ forvejen døjer med allergi, høreproblemer eller migræne. Undervisningen og forskningsprojektet tager også alt for meget tid. Folk har børn og job at passe. Desuden savner de studerende, at der gøres rede for opfyldelsen af de konkrete læringsmål i studieplanen. De forstår ikke formålet med det, vi laver. Hvor skal vi hen? "Vi får ikke noget ud af det, mens I får data til jeres projekt," siger én. "Vi får ikke nok for de penge, vi har investeret $i$ vores uddannelse," siger en anden. "Vi vil have nøjagtige timeplaner og vide, hvorfor vi går her!"8

Det er naturligvis ikke alle, der deltager i kritikken. Nogle prøver at fastholde de mere positive oplevelser. På et tidspunkt oplever jeg alligevel, at det hele bliver for meget. Jeg har ikke lyst til bare at sidde og tage imod. Tormod og jeg bliver nødt til at komme de studerende $i$ møde, ikke bare ved at lytte til kritikken, men ved at svare ordentligt, ud fra vores eget ståsted:

Først svarer Tormod, at han er imod de studerendes syn på sig selv som forbrugere af en på forhånd fastsat ydelse, som vi, sammen med institutionen, skal levere. Han argumenterer for, at en studerende er en producent snarere end en konsument, og for,

${ }^{8}$ Gengivelser fra egne notater taget undervejs på mødet. 


\section{H. Illeris}

at dette $i$ høj grad også kommer til at gælde, når de skal skabe sig et arbejdsliv som kunstnere/undervisere/forskere efter studiet. Desuden svarer han, at det ikke er de studerende, vi forsker på, men uddannelsen, og han understreger, at dette er en type aktionsforskning, hvor vi på frivillig basis har forsøgt at involvere flest mulige som samarbejdspartnere.

Derefter er det min tur. Jeg svarer, at jeg ikke ville kunne stå inde for at levere en målstyret undervisning, hvor der ikke er plads til at eksperimentere og arbejde med uforudsete hændelser. At det for mig er helt centralt at arbejde i et åbent felt, ikke bare når det gælder kunst og forskning, men også når det gælder pædagogik og undervisning. At kunst, pædagogik og undervisning er praksisformer, som hele tiden er $i$ forandring, og at vi i mine øjne ville gøre et dårligt job som undervisere, hvis vi forsøgte at pinde disse praksisformer ned til opfyldelsen af på forhånd fastsatte kompetencemål.

Efterhånden falder situationen til ro. Vi begynder at diskutere på en mere nuanceret måde, og stille og roligt når vi til en slags fælles forståelse og en enighed om, hvad vi kan gøre fremover. Teatret er allerede $i$ fuld gang med at blive forbedret, og vi skal blive tydeligere $i$ undervisningsplanlægningen. Desuden skal de etiske retningslinjer for de studerendes deltagelse $i$ forskningsprojektet nedskrives punkt for punkt. Alt sammen fornuftige løsninger på en række fælles dilemmaer.

\section{Dilemma 1: lighedens paradokser}

Rancière bruger begrebet dissens for at indikere det moment, hvor mennesker konstituerer sig selv som subjekter ved at kræve, eller rettere performe, lighed. Hvor meget kritisk pædagogisk tænkning (Giroux, 2011; McLaren, 1995) mener, at frigørelse kan foregå ved at bekæmpe ulighed inden for uddannelsessystemet, mener Rancière (1999, 2010), at forandring opstår, når de, som oplever sig som undertrykte, gennem

en viljesakt begynder at udøve dissens. Ved således at tage lighed som en forudscetning for kommunikation i stedet for som et mål, rekonfigurerer de den eksisterende sociale orden ved slet og ret at skabe anderledes måder at 'gøre subjektivitet' på, og som en konsekvens heraf en anderledes måde at 'gøre fællesskab' på. I Rancières (2010, s. 8) terminologi skabes nye delinger af det sanselige, forstået som nye forhold mellem væremåder, gøremåder og talemåder.

Som nævnt i indledningen kunne Art as Education/Education as Art ses som et forsøg fra Tormods og min side på at træde ud af universitetets undertrykkende orden for at skabe en dissens, som ikke anerkender standardiseringen, men som i stedet går i gang med at praktisere en anden måde at tænke uddannelse på, med udgangspunkt i andre 
idealer end dem, der kendetegner den aktuelle deling af det sanselige. Da efterårssemesteret var gået i gang, så vi imidlertid, at nogle af de studerende forstod projektet på en ganske anden måde, end vi selv gjorde. I deres optik var der ikke tale om en frigørelse, men snarere om et forsøg fra lærernes side på at etablere en form for alternativ orden, som brød med de ønsker og forventninger, som de mente-retmæssigt og med udgangspunkt i universitetets beskrivelser - at kunne have til deres studie. Det paradoksale var således, set med vores øjne, at mange studerende, bevidst eller ubevidst, kæmpede for at opretholde uligheden, så undervisning kunne finde sted på mere eller mindre traditionelle præmisser. De positionerede sig i klassiske roller som 'elever', og de blev frustrerede i de situationer, hvor de oplevede, at vi ikke opfyldte vores forpligtelser til på den ene eller den anden måde at lare dem noget. De følte sig forvirrede og oplevede, at de spildte tiden.

Som jeg tolker det, handlede en del af de klager, der kom til udtryk på evalueringsmødet, umiddelbart om denne forvirring: Hvor skal vi hen? Hvad får vi ud af dette? Og ikke mindst: Hvorfor kan vi ikke bare have det nogenlunde, som vi plejer, i stedet for at blive udsat for alle mulige forventninger om, at vi skal træde ud af den trygge position som studerende og i stedet forsøge at positionere os som kunstnere og/eller forskere? Og konklusionen (sat lidt på spidsen): Dette har vi ikke bedt om. Dette vil vi ikke være med til!

Tormod og jeg erfarede altså, at vores ambition om lighed åbnede for nye erfaringer af ulighed, og at disse erfaringer endte med at gå begge veje: Efterhånden som de studerende begyndte at tvivle på vores intentioner som lærere/forskere, begyndte vi selv at tvivle på vores projekt. Vi oplevede imidlertid også, at vi, netop ved dette højspændte evalueringsmøde, fik skabt nogle åbninger, som gav os alle et mere nuanceret syn på vores fælles situation. De studerendes frustration gav, koblet med vores egen usikkerhed, mulighed for, at der - måske for første gang i forløbet-faktisk blev skabt en ny deling af det sanselige, en mulighed for en reel lighed mellem deltagerne i det sociale rum.

En vigtig ting for Tormod og mig som lærere og forskere var således, at vi ved mødet fik mulighed for at etablere en klar og tydelig dissens over for den traditionelle uddannelseslogik, flere af de studerende valgte at forsvare. Situationen var, $i$ hvert fald for mit eget vedkommende, karakteriseret ved en ekstrem intensitet, en blanding af affekt og klarhed, en mulighed for at stå tydeligt frem og virkelig fortælle, hvorfor jeg mener, at kunst, uddannelse og forskning ikke kan styres af læreplaner alene, men må have karakter af uforudsigelige, eksperimenterende praksisser. Hermed trådte jeg endegyldigt ud af rollen som den, der skulle varetage de studerendes læringsproces i henhold til udefrakommende regler og konventioner for i stedet at genopfinde min egen position gennem, hvad Rancière definerer som subjektifikation, nemlig

...the production through a series of actions of a body and a capacity for enunciation not previously identifiable within a given field of experience, whose identification is thus part of the reconfiguration of the field of experience (Rancière, 1999, s. 35). 
Som socialt orienteret kunstnerisk proces var der i forlængelse heraf tale om et tilblivelsens øjeblik, hvor muligheden for at arbejde med en ny social form kom til syne. Hvor banalt det end kan forekomme, fikTormod og jeg først her muligheden for reelt at deltage i et fællesskab, som på den ene side nok var kendetegnet ved fortsat at være hierarkisk, med os som lærere og de studerende som elever, men hvor denne fordeling ikke længere bare var en institutionelt bestemt 'naturtilstand', som vi kæmpede med, uden at der rigtig skete noget, men et resultat af tydelige og bevidst valgte fælles konfigurationer - en virkelighedsfordobling, som jeg skal diskutere mere indgående i det næste afsnit.

\section{Dilemma 2: social kunst, relationalitet og antagonisme}

Rancière skriver i bogen The Emancipated Spectator (2009), at det æstetiske fællesskab er politisk, netop fordi det $i k k e$ bygger på en på forhånd givet forestilling om nærhed og samhørighed, men snarere på eksperimenter, leg og fiktion, og dermed hvad han kalder for dis-identifikation:

The aesthetical effect is initially an effect of dis-identification. The aesthetic community is a community of dis-identified persons. As such it is political because political subjectification proceeds via a process of dis-identification (Rancière, 2009, s. 73).

Det betyder, at det æstetiske potentiale $\mathrm{i}$ at se en uddannelse som et kunstværk ikke ligger $\mathrm{i}$ et på forhånd tilrettelagt design af deltagelsens former, men snarere i muligheden for, i det mindste glimtvis, at praktisere en anderledes og ikke på forhånd styret deling af det sanselige. I det æstetiske fællesskab kan roller omfordeles og leges med, men samtidig betyder dette, at frigørelsen ikke ligger i rolledelingen, men i den lighed, der opstår gennem selve legen: dis-identifikationen. Med inspiration fra Friedrich Schillers (1996/1795) æstetiske opdragelse, mener Rancière, at æstetik, pædagogik og politik er tre sider af samme sag, fordi dissens i hans optik altid udspringer af et æstetisk moment med potentiale for at udløse pædagogiske og politiske konsekvenser.

Vi oplevede undervejs i semesteret, at det var vanskeligt at få idéen om uddannelsen som kunstværk implementeret som en naturlig del af undervisningen. I stedet var det et emne, som blev drøftet på de månedlige erfaringsdelinger, men uden at disse diskussioner kastede andet af sig end mere eller mindre spekulative betragtninger, som i sig selv var frugtbare, men som manglede tilstrækkelig struktur og overbevisning til at blive taget videre. Den fiktionskontrakt, vi, med inspiration fra samtidskunsten, havde tænkt at indgå med deltagerne, blev i dagligdagen næsten glemt til fordel for alle de konkrete problemstillinger, vi mødte.

Vælger vi ikke desto mindre at se nærmere på ideen om education as art, bliver det interessant at se nærmere på, hvilken type social kunst og hvilke pædagogisk-æstetiske potentialer der i så fald var tale om. I udviklingen af projektet havde Tormod og jeg som nævnt støttet os til Bourriauds (2005) teori om relationel æstetik. Her er idéen, at god kunst har pædagogisk potentiale, fordi den åbner en lille sprække ind mod 
kvalitativt bedre livsformer ved at skabe kortvarige, men autentiske oplevelser af fællesskab (Illeris, 2015). I løbet af uddannelsens første semester var der imidlertid, som vi har set, ikke bare tale om et harmonisk fællesskab, men mere om et socialt samvær præget af spændinger og indbyrdes modsætningsforhold, sådan som det også kom til udtryk på evalueringsmødet. Hvis vi skal se på denne virkelighed som et socialt kunstværk, må vi derfor supplere Bourriauds feel good-teori med teorier, der orienterer sig mod kunst som konfliktuel og mod en idé om, at læring primært foregår gennem konfrontation med radikal anderledeshed.

I direkte opposition til Bourriaud mener Bishop (2004), at god social kunst bør være antagonistisk. I forlængelse af 70'ernes politiske kunst fremhæver hun kvaliteten ved kunstprojekter, der får os til at lære noget 'på den hårde måde' præget af indre modstand og gerne en oplevelse af ubehag og fremmedgjorthed. Bishop støtter sig på Rancière, når hun skriver, at god social kunst er kunst, der iscenesætter et spændingsfelt mellem levet liv og æstetisk dis-identifikation:

Good art, implies Rancière, must negotiate the tension that (on the one hand) pushes art towards 'life' and that (on the other) separates aesthetic sensoriality from other forms of sensible experience. This friction ideally produces the formation of elements 'capable of speaking twice: from their readability and from their unreadability' (Bishop, 2012, s. 29-30).

Ser man på undersøgelsen gennem disse briller, får man øje på de transformative kunstneriske læreprocesser, som følger med det ukomfortables æstetik, og som omhandler, hvordan man kan lære at bebo paradokser uden at ophæve dem (Illeris, 2018). De spændinger og fælles oplevelser, der førte frem til evalueringsmødet, er i denne forstålse eksemplariske, fordi de udfordrer de 'gode' konsensus-baserede idealer om lighed og inklusion for i stedet at stille skarpt på 'onde' følelser som akavethed, ubehag og konflikt som nødvendige for, at noget nyt kan opstå. Således var første semester på Master $i$ kunstfag et vellykket socialt kunstværk, netop på grund af de uforudsigelige muligheder for rekonfiguration og genskabelse gennem konflikt og virkelighedsfordobling, som det gav deltagerne mulighed for.

Man kan imidlertid også vælge at betragte Art as Education/Education as Art gennem et tredje sæt kunstteoretiske briller, som fokuserer på den pædagogiske værdi af kunstprojekter, der udfolder sig over længere tid, og som indebærer hårdt arbejde $\mathrm{i}$ form af forhandling. I sin teori om social kunst fremhæver kunsthistorikeren Kester (2011) denne type projekter som "..site-specific collaborative projects that unfold through extended interaction and shared labor" (s. 9), og han definerer praksisformen som ".. a sequential unfolding, extended through the cumulative experience of discrete moments of interaction and negotiation, conflict and reconciliation" (s. 104). Kester kritiserer både Bourriaud, Bishop og Rancière for på forskellig vis at undvige fællesskabets egentlige grundlag: kompromiserne, forhandling og genforhandling, det slidsomme samvær over tid, defineret gennem det amerikanske ord labor. Kester (s. 60) er kritisk overfor Bishops brug af Rancières æstetiske teori, fordi han mener, at denne understøtter polariseringen mellem hengivelse og kritik ved på ophøjet vis 
at fremhæve muligheden for et 'spil' imellem dem i stedet for at interessere sig for, hvordan disse reelt bliver forhandlet om og om igen i konkrete sociale kunstprojekter. Således åbner Kesters tilgang til kunst for en pædagogisk-æstetisk praksis, hvor transformation ikke foregår som en række enkelthændelser, men som et nuanceret forløb, der udspilles over tid.

I relation til Art as Education/Education as Art kan man således sige, at hvor udgangspunktet for projektet lå i Bourriauds forestillinger om det gnidningsløse, sanseligt funderede samvær, udviklede undersøgelsen sig snarere i retning af æstetisk antagonisme a la Bishop. Imidlertid ville det være forsimplet at stoppe ved denne konklusion, for hvis vi så bare kigger på den ene time, evalueringsmødet varede, så er det tydeligt, at også det udviklede sig gennem tidens og arbejdets seje former: fra at være baseret på modsætninger og sammenstød til at dreje sig om forhandling og forsøg på gensidig forståelse og herigennem på den langsomme, men nødvendige åbning for nye, forsigtige forskydninger i den fælles sociale form.

\section{Afslutning: At bebo praksis som pædagogik, som politik, som kunst- og som forskning}

Med Rancières dissens-begreb flyttes fokus fra uddannelse som et på forhånd defineret felt til at være den gestus, som sætter en bevægelse i gang. Dissens er den forestilling, som danner udgangspunkt for forhandling: forestillingen om lighed. I en tid, hvor ulighed fra politisk side i stigende grad bliver set på som et positivt fundament for samfundet, må det være ikke bare politikkens, men også pædagogikkens og æstetikkens opgave at udøve dissens gennem at etablere praksisformer, der muliggør rekonfigurationer af denne dominerende orden og åbner for anderledes delinger af det sanselige.

Afslutningsvis vil jeg dog gerne supplere Rancières perspektiv med at sige, at hvis første semester på Master $i$ kunstfag var et socialt kunstværk, så drejede det sig ikke bare om at udøve lighed som en pædagogisk-æstetisk handling, men om at udøve lighed som arbejde. Den slidsomme daglige forhandling. Langsommeligheden. Tidsperspektivet. Det at lære hinanden at kende, som udgangspunkt ikke bare for pædagogisk praksis, men også for æstetisk praksis og dermed for kunst. I løbet af efterårssemesteret var der øjeblikke af indsigt og klarhed, men subjektifikation var også noget, der fandt sted over tid: Mere end nogensinde har jeg oplevet vigtigheden af, sammen med studerende og kolleger, at bebo min egen praksis, både som pædagogik, politik og kunst.

Tid kom også til at spille en vigtig rolle i selve forskningsprocessen, fordi processen hele tiden forandrede sig og var i tilblivelse. Fra at have tænkt praksisstyret aktionsforskning som en overordnet metodisk tilgang, blev det efterhånden svært at adskille metoden fra det daglige liv. Uddannelsen var metode, æstetikken var metode, det daglige samvær og konflikterne var metode. Skrivningen og publiceringen af denne artikel er også metode, ligesom det møde vi har i næste uge med de studerende, som 
nu går på andet år og er i fuld gang med deres afsluttende masteropgaver, også er det. Og Tormods og mine fortsatte samtaler og fælles videreudvikling af projektet er kunstbaseret metodeudvikling in the making.

På den måde sammenflettes forskning, kunst og pædagogik som levet liv og som noget, der manifesteres som kreata når lejlighed byder sig-præsentationer, visualiseringer, materialiseringer, skrivning og undervisning. I stedet for at forsøge at repræsentere en virkelighed, som har fundet sted, forsøger ikke-repræsenterende, praksisstyret og kunstbaseret forskning at bruge det generede materiale til at skabe nye videns konstellationer, som kan operere i nutiden og være med til at skabe uforudsigelige sammenvævninger, som bevæger sig videre-ind i fremtiden (Vannini, 2015, s. 12). Materiale forbundet med Art as Education/Education as Art genereres fortløbende. Denne artikel er en hændelse, en af flere manifestationer undervejs.

\section{Tak}

Jeg vil gerne takke deltagerne i undersøgelsen, både studerende og kolleger, for godt samarbejde gennem processen og i den fælles skabelse af kreata undervejs. Jeg vil særligt takke min gode ven og kollega Tormod Wallem Anundsen for den fælles udvikling og fortsatte realisering af Art as Education/Education as Art. Tak desuden til Karsten Arvedsen og Liora Bresler for opmærksomme læsninger af manuskript og abstract til denne artikel.

\section{Forfatteromtale:}

Helene Illeris er ph.d. i billedpædagogik fra Danmarks Pædagogiske Universitet og professor i kunstfagdidaktik ved Universitetet i Agder (UiA). Hendes forskning omhandler kunst- og billedpædagogik med fokus på samtidskunst, visuel kultur og bæredygtighed. Helene er tidligere leder af det nordiske forskernetværk Contemporary art and visual culture in education (CAVIC) og leder nu, sammen med professor Tony Valberg, forskningsgruppen Kunst og sosiale relasjoner ved UiA.

\section{Litteratur}

Biesta, G.J.J. (2011). God uddannelse i målingens tidsalder - etik, politik, demokrati. Aarhus: Klim.

Bishop, C. (2004). Antagonism and Relational Aesthetics. OCTOBER, 110 (Fall), 51-79.

Bishop, C. (2012). Artificial Hells: Participatory Art and the Politics of Spectatorship. New York, NY: Verso.

Bourriaud, N. (2005). Relationel estetik. København: Det Kongelige Danske Kunstakademi.

Freire, P. (1970). Pedagogy of the oppressed. New York: Seabury Press.

Giroux, H. (2011). On Critical Pedagogy. New York: Bloomsbury Academic.

Haseman, B. (2006). A Manifesto for Performative Research. Media International Australia Culture and Policy, (118), 98-106.

Helguera, P. (2011). Education for socially engaged art: A materials and techniques handbook. New York: Jorge Pinto Books.

Illeris, H. (2015). 'Just building': Togetherness as art and education in a Copenhagen neighborhood. Visual arts research, $41(1), 67-83$.

Illeris, H. (2017). Subjectivation, togetherness, environment. Potentials of participatory art for Art Education for Sustainable Development (AESD). InFormation. Nordic fournal of Art and Research, 6(1), 1-16.

Illeris, H. (2018, under udgivelse). "The poetic self is not a fiction"- undersøgelser af æstetisk erfaring i kollektive læreprocesser med samtidskunst. I M. Blok Johansen (red.), Estetik og Pcedagogik. København: Akademisk Forlag. 


\section{H. Illeris}

Kester, G.H. (2011). THE ONE and THE MANY. Contemporary collaborative art in a global context. Durham: Duke University Press.

Leavy, P. (2018). Introduction to Arts-Based Research. I P. Leavy (red.), Handbook of Arts-Based Research (s. 3-12). London: The Guildford Press.

McLaren, P. (1995). Critical Pedagogy and Predatory Culture. London: Routledge.

Nielsen, B. S. \& Nielsen, K. A. (2015). Aktionsforskning. I S. Brinkmann \& L. Tanggaard (red.), Kvalitative metoder. En grundbog (s. 113-135). København: Hans Reitzels Forlag.

Pedersen, O. K. (2011). Konkurrencestaten. København: Hans Reitzels Forlag.

Podesva, K.L. (2007). A PedagogicalTurn: Brief Notes on Education as Art. Fillip 6, Summer 2007. Downloaded 06.03.2018 fra https://fillip.ca/content/a-pedagogical-turn.

Rancière, J. (1999). Dis-agreement. Politics and Philosophy. Minneapolis: University of Minnesota Press.

Rancière, J. (2009). The Emancipated Spectator. New York: Verso Books.

Rancière, J. (2010). On Ignorant Schoolmasters. I C. Bingham \& G. Biesta (red.), Facques Rancière: Education, Truth, Emancipation (s. 1-24). London: Continuum.

Rogoff, I. (2006). Academy as potentiality. I A. Nollen (red.), A.C.A.D.E.M.Y. (s. 13-20) Frankfurt am Main: Revolver.

Rogoff, I. (2010). Turning. I P. O’Neill; M. Wilson (red.), Curating and the Educational Turn (s. 32-46). London: Open Edition.

Rogoff, I. (2016). Starting in the Middle: NGOs and Emergent Forms For Cultural Institutions. I J. Burton, S. Jackson \& D. Willsdon (red.), Public Servants Art and the Crisis of the Common Good (s. 465-479). Boston: MIT Press.

Schiller, F. (1996/1795). Menneskets cestetiske opdragelse (Oversat fra tysk af Per Øhrgaard). København: Gyldendal.

Staunæs, D. \& Bramming, P. (2011). Øyeblikksbilder og kyborghet. Autofotografering og bildebasert forskning. I K. Fangen og A.-M. Sellerberg (red.), Mange ulike metoder (s. 100-115). Oslo: Gyldendal Akademisk.

Tribbensee, A. (2015) Irit Rogoff/RETHINKING ART EDUCATION / talking about Fugitive Study, infrastructure and education. Forelesing 06.08.2015. Tilgang 06.03.2018 på https://www.youtube.com/ watch?v=VVNxZunelB0

Vannini, P. (2015). Non-representational research methodologies: An introduction. I P. Vannini (red.), Nonrepresentational methodologies: Re-envisioning research (s. 1-18). London: Routledge.

Østern, T. P. (2017). Å forske med kunsten som metodologisk praksis med aesthesis som mandat. fournal for Research in Arts and Sports Education, Special issue, $\AA$ forske med kunsten, Vol 1, No 5 (2017), 7-27. DOI: http://dx.doi.org/10.23865/jased.v1.982 (tilgang 06.03.2018) 